Article

\title{
Erich Auerbach and His "Figura": An Apology for the Old Testament in an Age of Aryan Philology
}

\section{Avihu Zakai ${ }^{1}$ and David Weinstein ${ }^{2, *}$}

1 The Hebrew University of Jerusalem, Jerusalem 91905, Israel; E-Mail: avihuzakai@ gmail.com

2 Wake Forest University, Political Science Department, Tribble Hall, Winston-Salem NC 27109, USA

* Author to whom correspondence should be addressed; E-Mail: weinstd@wfu.edu;

Tel.: +336-758-5133; Fax: +336-758-6104.

Received: 16 January 2012; in revised form: 27 March 2012 / Accepted: 6 April 2012 /

Published: 13 April 2012

\begin{abstract}
Auerbach's goal in writing "Figura" and Mimesis was the rejection of Aryan philology and Nazi barbarism, based on racism, chauvinism and the mythologies of Blood, Volk and Soil, which eliminated the Old Testament from the Christian canon and hence from European culture and civilization. Following the Nazi Revolution of 1933 and the triumph of Aryan philology, Auerbach began writing "Figura," published in 1938, where he provided an apology for the Old Testament's validity and credibility, striving to prove that the Jewish Bible was inseparable from the New Testament contrary to the claims of Aryan philology and Nazi historiography. Auerbach's "Figura" should be considered not merely as a philological study but also, and more importantly, as a crucial stage in his response to the crisis of German philology with Mimesis, in turn, seen as his affirmation, against Aryan philology's Nazi racist and völkish views, of the humanist, Judeo-Christian foundation of European civilization.
\end{abstract}

Keywords: philology; Figura; allegory; Arian philology; Nazi historiography

\section{Introduction}

We must emphasize with all decisiveness that Christianity did not grow out of Judaism but developed in opposition to Judaism. 
Moses and Christ [are] related as figure and fulfillment.

Erich Auerbach, "Figura," 1938

Away with the Old Testament! A Christianity which still clings to the Old Testament is a Jewish Religion, irreconcilable with the spirit of the German people.

Demand by the German Christians in the rally at Berlin Sportpalast, 13 November 1933

[Figural interpretation] wished to preserve the full historicity of the Scriptures along with the deeper meaning.

Erich Auerbach, "Figura," 1938

Did Christianity arise out of Judaism being thus its continuation and completion, or does it stand in opposition to Judaism? To this question we respond: Christian faith is the unbridgeable religious contradiction to Judaism.

“The Godesberg Declaration" of the Evangelical Lutheran Church, April 4, 1939

[Auerbach's figural interpretation] asserted both the historical reality of the Old and the

New Testaments and also their providential connectedness.

Lowry Nelson, Jr. “Erich Auerbach: Memoir of a Scholar,” Yale Review 69 (1979-80)

In the "Introduction" to his Literary Language \& Its Public in Late Latin Antiquity and in the Middle Ages, 1958, Erich Auerbach (1892-1957) described the close, inextricable connection in his thought between philology and ideology, thus illuminating his unique approach in the field of "philology and literary expression," and showing how intrinsically connected his philological enterprise was to "the inward and outward crises of Europe" of his times [1]. Auerbach claimed that in comparison to other prominent philologists of his time, such as Karl Vossler (1872-1949), Ernst Robert Curtius (1886-1956) and Leo Spitzer (1887-1960), the source of his work was unique: "My work" he wrote "shows a much clearer awareness of the European crisis [2]."

It is our thesis in what will follow that Auerbach's philological, historical and philosophical enterprise in "Figura" (1938) and Mimesis: The Representation of Reality on Western Literature (1946) was directed against a very specific and well-defined crisis in Germany and Europe of his time. Auerbach referred in the above words not only to the general political and social crises of his time in Germany [3], but also, and most importantly, to a specific crisis in his own discipline, namely the crisis of philology, the development of Aryan philology and its eventual triumph in the Third Reich following the Nazi Revolution of 1933. Aryan philology was based on racism, anti-Semitism, narrow nationalism and sheer chauvinism. It strove to eliminate the Old Testament from the Christian canon, and, hence, from the very fabric of European culture and civilization [4]. Our goal here is to show and analyze the extent to which Aryan philology influenced Auerbach's thought and motives in the writing of "Figura." 


\section{Arian Philology}

Based on the legends and mythologies of "Blood, Volk and Soil"-Blut und Boden, the major slogan of Nazi racial ideology which focused ethnicity based on blood, folk and homeland, HeimatAryan philology was a unique German racist, chauvinist and anti-humanistic philology, which strove to fashion new Aryan origins of the German people, to shape a new Germanic or Nordic Christianity, to reject and eliminate the Old Testament from the Christian canon, and thus to construct new origins, aims and goals, for the history of the German people in particular and of Western civilization in general. Much of Auerbach's works, but most specifically "Figura" and Mimesis, were directed against the racist, chauvinist and anti-Semitic premises of Aryan philology [5].

During the Weimar Republic, "Philology had become a metaphor for numbing, drudgery, authoritarian discipline [6]." In contrast, Auerbach's philology is humanistic, or a philological humanism in other words, meaning a philology which is not based on racism, nationalism, chauvinism and Aryanism. He was a humanist philologist who stressed the humanist dimensions of Western culture and literature in contrast to Aryan, racist, philology. Against the German myths of Blood, Volk, Soil and Aryanism, he strove to prove the origins of European humanist civilization. Auerbach's narrative therefore is the narrative of Western civilization, not of specific race or ethnic group of people. Having advocated philological humanism in place of Aryan, racist philology, Auerbach rather promoted the Judeo-Christian humanist tradition of Western civilization. His was then the struggle of humanist philologist, of "historicist humanism" [7], against Aryan philology's de-canonization of the Old Testament and Nazi barbarism. Auerbach believed in historicism, or that mode of mode of thinking that assigns a central and basic significance to a specific context, such as historical period, geographical place and local culture. As such it stood in contrast to individualist theories of knowledge such as empiricism and rationalism, which neglect the role of history and traditions.

Aryan philology in Germany was inextricably linked to ideology and history as it tended to uphold Nazi racist and völkish ideology. That the elimination of the Old Testament from the fabric of German life and culture became central in Nazi ideology can be clearly seen in the thought of the influential Nazi intellectual Alfred Rosenberg (1893-1946), who was one of the main advocates of key Nazi ideological creeds such as racial theory, persecution of the Jews, Lebensraum ("habitat" or literally "living space"), and more. For Rosenberg, "the eternal Aryan values were contrasted to JudaeoChristian depravity." Hence, he declared: "The Old Testament as a book of religious instruction must be abolished once and for all. With it will end the unsuccessful attempts of the last one-and-a-half millennia to make us all spiritual Jews." (Emphasis added). Regarding Jesus himself, Rosenberg claimed that as "for Jesus' ancestry is concerned, there is not the slightest reason to believe" that "Jesus was of Jewish ancestry [8]."

The struggle in Germany against the Jewish Bible, and against Jewish influence in general, reached its height after the Nazi Revolution of 1933, which signaled also the triumph of Aryan philology in Germany. A clear example of the influence of omnipresence Anti-Semitism fueled by combined forces of Aryan philology and Nazi historiography can be clearly seen in the mass rally organized along Nazi party style by the German Christians-Deutsche Christen-on 13 November 1933 at the Berlin Sportpalast. The German Christians movement, officially organized in 1931 as the Nazi Wing of the Evangelical Church, initially emerged during the 1920s "as an effort to synthesize Christianity with a 
rabid German Nationalism [9]." It was established "to ensure the racial survival and de-judaizing the Christian faith and had been represented in sundry Church parliaments [10]." In the 1933 Berlin Sportpalast rally, before a packed hall of 20.000 supporters, banners proclaiming the unity of National Socialism and Christianity were interspersed with the omnipresent swastikas. A series of speakers addressed the crowd's pro-Nazi sentiments with ideas such as the removal of all pastors unsympathetic with National Socialism, the expulsion of members of Jewish descent, etc. Not the least among these demands was "the removal of the Old Testament from the Bible," or from the Christian canon, and the adoption of a more "heroic" and "positive" interpretation of Jesus, who in pro-Aryan fashion should be portrayed as battling mightily against corrupt Jewish influences [11].

According to Nazi Pastor Dr. Reinhold Krause, who preached at the Berlin rally, German Protestantism needed a "second Reformation." Hence he submitted three reforms, among them the "Elimination of the Old Testament and of 'palpably misrepresenting or superstitious passages in the New Testament' [12]." (Emphasis added). Krause demanded the elimination of the Old Testament because of its Jewish "commercial morality" and "unedifying stories of "cattle-dealers and pimps," as well as the rejection of the theology of "Rabbi Paul [13]." Needless to say, that "meeting enthusiastically adopted a resolution supporting Dr. Krause's reforms [14]." Indeed, many "Deutsche Christen theologians who were loyal to Nazi ideology rejected the OT [Old Testament], precisely because they thought of it as a Jewish book [15]." For example, Ludwig Müller (1883-1945), the leader of the German Christians and Reich's Bishop (1933) of the German Evangelical Church, declared in 1934: "We must emphasize with all decisiveness that Christianity did not grow out of Judaism but developed in opposition to Judaism [16]." (Emphasis in original).

In this broad historical, racial, Anti-Semitic and Aryan philological, context, Auerbach's "Figura" can be described as an apology for the Old Testament in an age of the crisis of German philology and the triumph of Aryan Philology following the Nazi revolution of 1933. Auerbach argued therefore that figuralism or typology "originated in early Christian efforts to show that Jesus Christ was indeed the Messiah and had fulfilled Jewish prophecies, by retrospectively explaining the Hebrew Bible as the 'Old' of the 'New Testament' [17]." By seeing that figural interpretation "asserted both the historical reality of the Old and the New Testaments and also their providential connectedness" [18], the credibility and validity of the Old Testament was thus fully asserted and its authority fully assured against the premises of Aryan philology. Likewise, Mimesis, which Auerbach began writing in 1942, the most decisive year in World War II in which the Battle of Stalingrad, the Battle of Midway in the Pacific Ocean, and El Alamein in North Africa all took place, is an apology for Western JudeoChristian humanist tradition in an age of peril, barbarism and tyranny. That is, it is an apology not in terms of regret, remorse, or sorrow but rather as a strong defense or justification. "Figura" and Mimesis are indeed an apologetic endeavor of a humanist apologist. Like Augustine and Pascal, to name only a few famous Christian apologists, Auerbach too wrote an apology — an apology for Western humanist civilization in a time of the gravest existential threat it faced. Apology is typically written by someone who claims to know the truth and strives to show it in its full colors in a world which denounced it; hence it is written in dark times of peril and danger threatening this truth. This applied as well to Auerbach, because, as René Wellek has written, what Auerbach produced "was oriented toward truth" [19] or, to use Auerbach's own words, toward "an absolute claim to historical truth [20]." 
Auerbach's seminal essay "Figura" [21] appeared in 1938, though its inception took place in Germany before Auerbach went into exile [22]. And after taking refuge in Istanbul in 1936, "Auerbach finished drafting the essay on figura from notes gathered before he had left Germany and from research undertaken in Turkey [23]." If this contention is right, and there is no reason to believe otherwise, then Auerbach began working on his famous essay after the Nazi Revolution of 1933, which also signaled the triumph of Aryan philology. Thus, although "Figura" is minted in the thick veins of medieval exegesis, it is our thesis that in this essay Auerbach enlisted philology in the service of humanist ideology, or in his struggle against the premises of Aryan philology. More specifically, he used philology in order to show that figural and not allegorical interpretation guided Western Christianity until the Age of Enlightenment, hence confirming the close and intrinsic connection between the Old and the New Testaments, in contrast to the racist, Anti-Semitic premises of Aryan philology.

Auerbach argued that the word figura, originated "in pagan antiquity," and was then developed by "the Church Fathers" into a system of singular figural interpretation of reality, which "was of the greatest historical importance," ([21], pp. 27-8) thus establishing close, intrinsic and inseparable ties between the Old and the New Testament, Judaism and Christianity. "Figura" thus signifies a unique mode of historical causation, "figural causation" [24], which is radically different from ancient, classic teleological notions of causality. Further, seeing that figura denotes an important Patristic mode of biblical exegesis, Aryan philology's aim to eliminate the Hebrew Bible from the Christian canon, and as a consequence to construct new origins and hence goals for the German people, clearly had no warrant and validity whatsoever. Indeed, Auerbach brought into the foreground in 1930s a thesis about figura, which was known only to modern medievalists and philologists [25], but the reason for that is more than clear: he fully understood that this thesis was vitally relevant to his own historical, political, ideological and philological context in his struggle against the premises of Aryan philology. His was then a grand mission of great proportions in "Figura:" to provide the meaning of figura and its humanist ramifications for the course of European civilization as it was used after the fashion of Saint Paul, Augustine, Aquinas and Dante. In the hands of Auerbach, then, figura, which was born "in the nexus of Judaism and Christianity," embodies "one of the conditions of the literary project of the West [26]." Philology, in other words, became in Auerbach's hands an ideological tool and figural interpretation was transformed into a formidable weapon against Aryan philology. Humanist ideology, thus became an essential part of philology, and philology became inseparable from ideology.

\section{3. "Figura" and "Allegory"}

In "Figura," Auerbach strongly insisted on a firm and rigid demarcation between "figura" and "allegory," or the Index figurarum and the Index de allegoriis [27], thus drawing a clear-cut contrast between "allegory, in which figure is feigned to illustrate a given proposition, and figura, in which both terms, the figure and the figured, are deemed real [28]." Basically, Auerbach explains, figure "differs from allegory in that allegory involves an abstract sign that leads beyond itself rather than to another real historical being" as in the case of figure [29]. Figura thus implies realism, and vice versa. Later on in Mimesis, Auerbach explained that one of the main differences between allegory and figura is that allegory moves "horizontally" on earth, or in the historical realm, while figura "vertically," thus connecting Heaven and earth or the sacred and the secular. Allegory is "horizontal," because it deals 
with the realm of "the temporal and causal," while figura is vertical since "both occurrences are vertically linked to Divine Providence [30]." Hence, as we will see later, figura and the figural view of reality denote eschatology and apocalypse.

Although acknowledging "the fact that allegoria is prominent in medieval exegesis," Auerbach nonetheless insisted "that figura is the dominant mode and that it replaces allegory as a category for the Christian interpretation of the Bible and the physical universe [31]." The figural view of reality is thus radically different from the allegorical one. In the broad historical and religious confines of the rise of Christianity, according to Auerbach, the "spiritualist-ethical-allegorical" interpretation had "little influence on the freshly converted people" to Christianity ([21], p. 55). One of the main sources for the different power and role Auerbach assigned to figura and allegoria lay in their different origins: "the figural method in Europe goes back to Christian influences, while the allegorical method derives from ancient pagan sources, and also that the one is applied primarily to Christian, the other to ancient materials" ([21], p. 63. Emphasis added). European literary culture's representation of reality thus, in accordance with Auerbach's newly acquired "anticlassical bias" [32], did not originate with the pagan classic Greeks, which the Nazis adored and worshiped, but rather with the Judeo-Christian heritage. This contention will later serve as the core of the first chapter in Mimesis.

Evidently, Auerbach considered "figura" as an example of "Ansatzpunkt, a major semantic point of departure providing insight into very large literary or cultural movements - in the case the separation between classical and Christian forms and attitudes." This important concept in Auerbach's philological philosophy leads us directly to the crucial issue of Auerbach's main aim in his famous essay, or in the words of Jesse M. Gellrich: "If the opposition of figure and allegory is such a point of departure, then what is the larger problem to which it provides access?" Auerbach's concern, argues Gellrich, is clearly "predominantly with the Christian departure from classical use of figura in rhetoric and oratory, but he also discusses the distinction from allegory, which he represents as Greek literary form and an Eastern influence fundamentally incompatible with the historical interests of Western exegesis." In sum, writes Gellrich, according to Auerbach "Tertullian and Augustine are to be separated from Origen and Philo of Alexandria, insofar as the Greek writers compose an allegorization that devalues the relevance of the historical record by rendering the entire Old Testament as a mere shadow show of moral concepts and future happenings [33]." (Emphasis added.) In contrast, according to Augustine, "what is the Old Testament but the New Testament veiled; and what is the New Testament but the Old Testament unveiled [34]." The Old Testament thus prophetically prefigures the New Testament, and the later could be read as a figural realization or interpretation of the Hebrew Bible. More specifically, in the context of the history of salvation and redemption, Figura denotes eschatology and apocalypse; hence it constituted a crucial dimension of sacred, providential history. In "Figura," therefore, Auerbach set out a transcendentalist scheme. In sum, by claiming the predominance of figura in Christian thought, Auerbach opposed "the spiritualist-ethical-allegorical method." ([21], p. 55).

This is the crux of the matter-figura signifies essentially an intrinsic, inextricable relationship between the Old and the New Testaments. Historically and theologically, there were two well-defined schools in early Christianity regarding the right interpretation of the Hebrew Bible. The Alexandrian allegorical school, which was influenced by the thought of the Hellenistic Jewish world in Alexandria in which Philo and others viewed the Bible in Platonic terms as essentially an allegory, which was later 
Christianized by Origen Adamantius of Alexandria in the third century, and the figural school of Tertullian and Augustine. Yet, while allegorization "devalues the relevance of the historical record" of the Hebrew Bible and hence its value as the history and the laws of the Jewish people, figura, in contrast, through the figural, typological interpretation of history, which is the essence of figura according to Auerbach, rather keeps and preserves it:

Figural interpretation establishes a connection between two events or persons, the first of which signifies not only itself but also the second, while the second encompasses or fulfills the first. The two poles of the figure are separate in time, but both, being real events or figures, are within time, within the stream of historical life ([21], p. 53).

Figural interpretation thus connects two events or persons in historical time; the first, the type, signifies itself and the second, while the second, the antitype, fulfils the first, or the type. In other words,

figura is something real and historical which announces something else that is also real andhistorical. The relationship between the two is similarity ([21], p. 29).

Later on in Mimesis, Auerbach elaborated this point, claiming that the "figural interpretation of history" implies "that every occurrence, in all its everyday reality, is simultaneously a part in a worldhistorical context through which each part is related to every other, and thus is likewise to be regarded as being of all times or above all time [35]."

These contentions, it should be stressed, are not merely philological semantic ones, but rather, ideological ontological in their nature, since, in the hands of Auerbach, they established the intrinsic, inextricable connections between the Old and the New Testament. The Christian interpreters thus viewed "the relationship between the earlier and latter events as 'genetic' and 'causal,' as willed by God and therefore "providential' [36]." As Auerbach constantly strove to show, "Moses and Christ" are "related as figure and fulfillment" ([21], p. 34). In the same vein, Adam, Moses, Joshua, and David in the Old Testament are all prefigurations of Christ in his earthly mission. Likewise, Eve is a figure of Ecclesiae and Passover is a figure Christ - the wine a figure of his blood and the bread of his body ([21], pp. 27-9, 31-2). Thus Bishop Eucherius of Lyon wrote in the fifth century: "The intention of the Old Testament is to point to the New by figures and prophecies; that of the New to kindle the minds of men to the glory of eternal beatitude" ([21], p. 44). Later on in Mimesis Auerbach elaborated on this theme, claiming the Old Testament's "episodes are interpreted as figures or phenomenal prophecies" [37], arguing that God is a "supratemporal figural conception;" hence in the Mystère d'Adam of the latter part of the twelfth century He "is called figura" and "figura salvatoris" [38].

Ultimately, according to Auerbach, the aim of figural interpretation "was to show that the persons and events of the Old Testament were prefigurations of the New Testament and its history of salvation" ([21], p. 30). Figural, typological historical interpretation was based on vertical structure, or a providential design, while traditional classical chronological historical interpretations were based on horizontal succession. Seeing that figural interpretation "asserted both the historical reality of the Old and the New Testaments and also their providential connectedness" [39], the credibility and validity of the Old Testament is thus fully asserted and its authority fully assured against the premises of Aryan philology. In other words, "typological system of exegesis, expounded philologically in 'Figura,' actually contains a philosophy of history [40]." Humanist philology thus denotes historicism, or 
humanist history in Auerbach's mind and vice versa. Evidently, one can find here the main reason why Auerbach emphasized repeatedly the dominance and predominance of figure in the life and thought of the early church and medieval history up through the eighteenth century [41]. Thus he argued:

The difference between Tertullian's more historical and realistic interpretation and Origen's ethical, allegorical approach reflects a current conflict ... one party strove to transform the events of the New and still more of the Old Testament into purely spiritual happenings, to 'spirit away' their historical characterthe other wished to preserved the full historicity of the Scriptures along with the deeper meaning. In the West the latter tendency was victorious ([21], p. 36. Emphasis added).

The triumph of figura in Patristic literature began with Tertullian in the third century and it reached its hegemonic culmination in the fourth century with Augustine. Both alike strove to reconcile the Old with the New Testament, claiming both parts of the Bible are the work of God. Figura thus became the foundation of the Christian conception of reality and, hence, of history. More specifically, figuralism or typology "originated in early Christian efforts to show that Jesus Christ was indeed the Messiah and had fulfilled Jewish prophecies, by retrospectively explaining the Hebrew Bible as the 'Old' of the 'New Testament' [42]." For example, "Joshua of the Old Testament serves as a figure for Jesus, and Jesus represents a fulfillment or completion of Joshua [43]." In sum, both parts of the Bible are essentially the work of God, an important contention Auerbach pressed against the premises of Aryan philology.

Historically, "figural interpretation was of great practical use for the [Christian] mission of the fourth and the following centuries," including of course, Auerbach noted with sheer irony, the conversion of the various German barbaric tribes ([21], p. 43). Furthermore, being a unique "interpretation of history" (([21], p. 57), figural interpretation determined for many centuries the Christian sense of time and vision of history, "or to put it more completely, the figural view of history was widespread and deeply influential up to the Middle Ages and beyond" ([21], p. 60). From the "fourth century on, the usage of the word figura and the method of interpretation connected with it are fully developed in nearly all the Latin Church writers," and since then, continues Auerbach, "in most European countries figural interpretation was active up to the eighteenth century," or the Age of Enlightenment ([21], pp. 34, 61). This was, in sum, Auerbach's response to Aryan philology's elimination of the Old Testament from the marrow of the Christian canon and the origins of Western civilization. More specifically, figural interpretation of reality "asserted that Jewish laws, customs, derivations, and philosophies were intrinsic_and inseparable — part of Western culture [44]."

Evidently, for Auerbach, figural realism, or the figural view of reality, is based on the overall figural interpretation of history. In this unique figural view:

history, with all its concrete force, remains forever a figure, cloaked and needful of interpretation. In this light the history of no epoch ever has the practical self-sufficiency which, from the standpoint both of primitive man and of modern science, resides in the accomplished fact; all history, rather remains open and questionable, points to something still concealed, and the tentativeness of events in the figural interpretation is fundamentally different from the tentativeness of events in the modern view of historical development. In the modern view, a provisional event is treated as a step in an unbroken horizontal process; in the figural system the interpretation is always sought from above; events are considered not in their unbroken 
relationship to one another, but torn apart, individually, each in relation to something other that is promised and not yet present.

Whereas in the modern view, the event is always self-sufficient and secure, while the interpretation is fundamentally incomplete, in the figural interpretation the fact is subordinated to an interpretation which is fully secured to begin with: the event is enacted according to an ideal model which is a prototype situated in the future and thus far only promised. ([21], pp. 58-9. Emphasis added)

We quote this passage at length because Auerbach will later make "needful of interpretation" central to his distinction between the Homeric and the Hebrew biblical style in the first chapter of Mimesis. In this book, the figural interpretation of history reached its apotheosis in Dante and after him it declined. Dante thus signified a climax of the figural interpretation in the Middle Ages. Later on, the French realist novels of the nineteenth century constituted yet another apotheosis in the representation of reality, but this time without the figural interpretation of history.

It should be noted, however, that the distinction Auerbach made between allegoria and figura in his philological enterprise has no factual, historical basis at all. In fact, according to Gellrich, rather "allegory eventually became the conventional category in medieval exegesis for describing the prefiguring characteristics of the Old Testament that Auerbach reserves for figura [45]." Likewise, Brian Stock argues that Auerbach's "obvious weakness lay in the field of allegory," namely his contention that figura and not allegory became the dominant mode in Western culture [46]. In view of these critical contentions, we may suggest that Auerbach's idiosyncratic distinction is rather an ideological and not solely philological one.

Auerbach's goal was to show that although figura originated "in pagan antiquity" it was uniquely developed by "the Church Fathers" into a system of singular, figural historical interpretation, which "was of the greatest historical importance." ([21], pp. 27-8) In its unique Judaeo-Christian usage and conception, Auerbach explained in Mimesis, figura is an Ansatzpunkt, thus introducing "an entirely new and alien element into the antique conception of history [47]." But as some have convincingly argued, "typology is another name for figura and scholars have long been aware that the rudiments of typology are discernable in the Aeneid," or in pagan, classical culture. For example, "Aeneas prefigures the emperor Augustus; when he is with Cleopatra he prefigures Mark Anthony; Dido prefigures Cleopatra. Note that all this is figura, not allegoria, according to Auerbach's distinction of terms [48]."

Yet, if the above is right about the use of figura in the pagan, classical world, this is not quite so regarding Auerbach's apocalyptic and eschatological notion of figura. For him, figura essentially denotes an important apocalyptic and eschatological dimension in sacred, providential history, thus unquestionably establishing an inextricable link between the Old and the New Testament. And there is no apocalyptic or eschatological dimension when we say that Aeneas prefigures the emperor Augustus, but it is rather clearly the case with regarding "Moses and Christ," since they are "related as figure and fulfillment," ([21], p. 34) and Christ's First and Second Coming are the most decisive apocalyptic and eschatological events in the sacred history of salvation and redemption. Accordingly, Auerbach argued that figura introduced a crucial point of semantic departure, an Ansatzpunkt, from the classical to the early Christian world or "an entirely new and alien element into the antique conception of history [49]." 


\section{Meaning and Significance of Auerbach's "Figura"}

Our goal here of course is not to refute the credibility and validity of Auerbach's thesis about figura, but ultimately to understand it. Why, then, did Auerbach insist on using this wrong and unwarranted distinction between figura and allegoria? The answer is clear: he strove to combat Aryan philology's rejection and exclusion of the Hebrew Bible. "Figura" then is "concerned predominantly with the Christian departure from classical use of figura in rhetoric and allegory." The details of this distinction and its validity should no detain us here, but suffice it to say that for Auerbach, figura is a clear and important instance of "Ansatzpunkt," a crucial point of departure which reveals the separation between forms and attitudes in the classical and Christian worlds [50]. The predominance of figura in Christian thought, according to Auerbach, served him well in his attempt to counter the decanonization of the Old Testament and hence its exclusion from the history of Western civilization. For, as Auerbach claimed, figura signified the relationship between two equally real persons, events, circumstances, etc. Now, if indeed he could prove that figural interpretation became predominant mainly in early Christianity, and not earlier in the pagan, classical world in which allegory was the dominant mode, then he could establish that a unique and indeed inseparable relationship existed from the very beginning between the Jewish and the Christian Bible. Philology, then, was essential to the ideological struggles and controversies in Nazi Germany. This is one of the main thrusts behind Auerbach's "Figura."

In contrast to figura, then, which preserved the historicity of the Old Testament, allegory endangered the validity and credibility of the Jewish Bible. Auerbach therefore associated "the historicity of recorded events with the figuring stories about the Hebrew Bible." Thus, although the "Hebraic narratives have historicity," they are "in danger of evaporating into mere 'signs' by the allegorizing intention of Hellenic form of thought." For in contrast to figura, Auerbach argued, allegory "disregarded" the "concrete, historical reality of the people and events in Old and New Testament narrative" (Emphasis added). As Gellrich has observed,

the preference for figura and the disapproval of allegory are recto and verso of a single attitude, an inclination to conserve the specific contribution of the Hebrews to the New Testament and to the contour of history that exfoliated from it in the Western Middle Ages [51].

Assuming that Gellrich is correct in his interpretation, we would like pose another question: why did Auerbach prefer the figural interpretation of reality over the allegorical one? And against whom was he trying "to conserve the specific contribution of the Hebrews to the New Testament"? Our answer is that he was trying to establish to the utmost the inseparable and inextricable relationship between the Old and the New Testament in contrast to Aryan philology. Auerbach explained that in the past, figural interpretation "had grown out of a definite historical situation, the Christian break with Judaism and the Christian mission among the Gentiles" ([21], p. 56). Yet now, in Nazi Germany during the 1930s, and in a clear twist of historical irony, Aryan philology was leading rather to an unprecedented total break with Judaism, this time by severing the ties not only with national history of the Jews but also with the figural interpretation of history, which is the heart of Christian sense of time and vision of history. Plainly, the price of severing ties with the Old Testament would be indeed very high and fatal in terms of the very essence of the Christian faith, namely Christianity would lose "its 
conception of providential history" ([21], 52), the basis of which was found essentially in figural interpretation. This was one of the gravest ramifications of Aryan philology.

The Church Fathers, explains Auerbach, tended indeed to "often justify the figural interpretation on the basis of certain passages in early Christian writings, mostly from the Pauline Epistles" ([21], p. 49). These passages sought "to strip the Old Testament of its normative character and show that it is merely a shadow of things to come" ([21], p. 50). In other words, the Old Testament in Paul's figural interpretation ceased to be "a book of the law and history of Israel and became from beginning to end a promise and prefiguration of Christ." Yet, as Auerbach emphasized, what the Old Testament lost "as a book of national history, it gained in concrete dramatic actuality" ([21], p. 51). Or more specifically, as Auerbach wrote later in Mimesis,

The Old Testament was played down as a popular history and as the code of the Jewish people and assumed the appearance of a series of 'figures,' that is of prophetic announcements and anticipation of the coming of Jesus and the concomitant events [52].

Thus, a major semantic turning-point, Ansatzpunkt, took place with the rise of the figural interpretation of history: "The total content of the sacred writings was placed in an exegetic context which often removed the thing told very far from its sensory based," or its immediate concrete historical context [53]. Subsequently, for Auerbach, "figural interpretation introduced by Paul when seeking to convert the Gentiles" acquires the "most fundamental consequences in the story that Mimesis tells [54]." Or as Auerbach wrote in Mimesis: "Paul and the Church Fathers reinterpreted the entire Jewish tradition as a succession of future prognosticating the appearance of Christ, and assigned the Roman Empire its proper place in the divine plan of salvation." For "millennia" this figural interpretation of history "undergoes an incessant and active development with the life of man in Europe [55]."

In contrast to figural interpretation, allegorical interpretation sought rather "to exclude the Old Testament altogether," which meant among other things that "Christianity would necessarily have lost its conception of a providential history, its intrinsic concreteness, and with these no doubt some of its immense persuasive power" ([21], p. 52. Emphasis added). For it is through the figural interpretation of sacred, providential history, based on figura and fulfillment, promise and its realization, from the Old to the New Testament, that Christianity acquired its power and validity hence establishing an inextricable connection between the Hebrew and the Christian Bible. "In the struggle against those who despised the Old Testament and tried to despoil it of its meaning, the figural method again proved its worth" ([21], p. 52. Emphasis added). This historical lesson applied not only to early Christianity but to Nazi Germany as well. Thus, although the above words referred to the struggle between the "Judaeo-Christians" and Paul's figural interpretation in early Christianity, Auerbach must have had in mind as well the proponents of Aryan philology in his own time. In other words, his acute awareness of the problem of eliminating the Old Testament in early Christianity may well arisen because of attempts to eliminate the Old Testament in his own time in Nazi Germany.

If Aryan philology strove to eliminate the Old Testament, then ironically, as Auerbach was quick to point out, it was rather the figural interpretation which "changed the Old Testament from a book of the people of Israel into a series of figures of Christ, and the Redemption." And it was rather in this form and in this context, "from which the Jewish history and national character had vanished," that "the 
Celtic and Germanic peoples, for example, could accept the Old Testament; it was a part of a universal religion of salvation" and necessarily "a universal vision of history" ([21], p. 52. Emphasis added). Readers of "Figura" can clearly see here an historical irony; while Germanic barbaric tribes received the Hebrew Bible in the long process of their Christianization from the fourth to the eighth century, modern German Nazi barbarians excluded and rejected it. Further, it was indeed not until "after the Reformation that Europeans began to regard the Old Testament as a Jewish history and Jewish law" ([21], p. 53). But first, the Old Testament

came to the newly converted people as figura rerum [substantive figure] or phenomenal prophecy, as a prefiguration of Christ, so giving them a basic conception of history, which derived its compelling force from its inseparable bond with faith, and which for almost thousand years remained the only accepted view of history. Consequently, the attitude embodied in the figural interpretation became one of the essential elements of the Christian picture of reality, history, and the concrete world in general" ([21], p. 53. Emphasis added).

One can clearly see in the above quote how humanist philology and ideology closely intertwined in Auerbach's mind. Not only were racist and Anti-Semitic Aryan philology and völkish historiography unwarranted, but it was the Old Testament which provided a sense of time and a vision of history, along with faith, to the Germanic tribes. Admittedly, only in exile and definitely not in Nazi Germany, could Auerbach write these words. Ironically, then, exile has its advantages and blessings too, or its "pleasures" and its "positive things [56]." An additional example to this sad irony can be seen in Auerbach's words that "it is quite possible that" Mimesis "owes its existence" to "the lack of a rich and specialized library. If it had been possible for me to acquaint myself with all the work that has been done on so many subjects, it might never have reached the point of writing [57]." Likewise, being in exile and out of the reach of Nazi authorities in Istanbul, Auerbach could now write in plain words about the German tribes and the transformation of the German Reformation without fear and trembling. "Virtue made of necessity has seldom been better exemplified than by Auerbach in his expulsion from his homeland [58]."

All this is crucially important, of course, not only to a discussion of "Figura" as an example of a philological Ansatzpunkt in general, but also to the Ansatzpunkt in Auerbach's philological enterprise in particular, namely his struggle against Aryan philology. "Turning a point of momentous cultural change upon a pivot of syntax (along with its meaning of course) was an art he fashioned for himself." This is more than clear in "Figura" in which he revealed "the great insight of his life," namely, figural interpretation, or the view "that all interpretation of Christian literature, as well as exact exegesis, depended on an assumed and traditional Christian doctrine that the New Testament is elaborately and fully an historical and typological fulfillment of the Old [59]." In other words, "Figura" decisively influenced the content and form of Mimesis: "the style of the Hebrew narrative has a definite place in Auerbach's historicism and he linked it to figura in his subsequent work, principally the study of Western realism in Mimesis." Hence in the first chapter in Mimesis, Auerbach set forth his famous claim "for the historicity in the Hebraic style by contrasting Old Testament narrative with the Hellenic style of the Homeric poems [60]."

We would like however to offer a different interpretation about this important link between "Figura" and Mimesis as well as the use of the style of the Hebrew narrative in the later work. 
Mimesis, Auerbach's mission in exile, was written as a grand tour of the Western humanist tradition in order to combat Nazism and Aryan philology. The question in his mind therefore was not only of "historicism" or "figural interpretation," which were very important issues in Auerbach's philological philosophy, but also his struggle against Nazi barbarism. Hence Auerbach used his findings in "Figura," about the style of the Hebrew narrative and the figural interpretation of history in Mimesis as well. We may say therefore that the essay "Figura" is a figura of Mimesis, or conversely, that Mimesis is the fulfillment and realization of "Figura."

That "Figura" was an important Ansatzpunkt in Auerbach's overall philological studies can be clearly seen also with regard to his first book on Dante. Auerbach informs us in "Figura," that Dante's Comedy is "based on figural conception." Yet, when writing his book on Dante in the late 1920s, continues Auerbach, "I lacked a solid historical grounding for this view." However, after developing, following the Nazi revolution of 1933, the historical meaning and philological significance of figura with its unique form and content in Western culture, he argues "I have now found the historical grounding; it is precisely the figural interpretation of reality" which "was the dominant view in the European Middle Ages" ([21], pp. 71-2). Later on, in Mimesis, Auerbach followed this point, claiming that the figural interpretation of reality "for millennia" underwent "an incessant and active development with the life of man in Europe [61]." Accordingly, "the earthly event is a prophecy or figura of a part of a whole divine reality that will enact in the future" ([21], pp. 71-2). "Figura" was thus clear evidence not only of a philological Ansatzpunkt but also of a historical and ideological transformation in Auerbach's thinking.

Evidence for this assertion can be clearly seen in the radically different views of Auerbach with regard of Beatrice in his first book on Dante and in his "Figura," in which Beatrice became a great, revelatory, prophetic figura according to the apocalyptic and eschatological dimensions inherent in this concept. In the book on Dante, Auerbach argued that Beatrice "is an allegorical figure" [62], but later in "Figura," Beatrice was radically transformed into "revelation incarnate," a figura who "finds the only possible salvation" for Dante ([21], pp. 72-3). Hence, "she is figura or idolo Christi" ([21], p. 75). Further, "Beatrice is not fiction. There really was a little girl in red dress whom Dante met, at the age of 9 , in the house of Portinari. This Beatrice (and unlike the seducing idols of courtly love) figured the beauty and the goodness of God [63]." "Figura" thus constituted an important philological, historical and ideological, Ansatzpunkt in the development of Auerbach's philological philosophical thought.

Auerbach concluded "Figura" with an important statement:

Our purpose was to show how on the basis of its semantic development a word may grow into a historical situation and give rise to structures that will be effective for many centuries. The historical situation that drove St. Paul to preach among the gentiles developed figural interpretation and prepared it for the influence it was to exert in late antiquity and the Middle Ages ([21], p. 76. Emphasis added).

We should read these words, especially the singular role attached here to St. Paul, in the gloomy, anti-Semitic context of Nazi Germany. "Figura" was published in 1938, and a year later, in May 1939, the "Institute for the Study and Eradication of the Jewish Influence on German Church Life" was established. At the opening ceremony of the Institute, its scientific director Walter Grundmann declared that the "elimination of Jewish influence on German life is the urgent and fundamental question of the present German religious situation [64]." The Institute was, of course, only the 
culmination of a long process in Germany, especially after the Nazi Revolution of 1933, in which Aryan philology gained the upper hand.

How a "word" grew "into a historical situation" was fundamental to Auerbach's unique philological way of interpretation. The word is the source of realism because "on the basis of its semantic development a word may grow into a historical situation and give rise to structures that will be effective for many centuries" ([21], p. 76). This approach stood at the foundation of his singular philosophy of realism that appeared later in Mimesis. Indeed, this central point—from "a word ... into historical situation" - can be equally applied not only to the concept of "Figura," which grew from a word into an important magisterial literary, historical interpretation, but also to Mimesis, which too was developed from a word into a majestic history of Western humanist literature.

\section{Conclusions}

When Auerbach concluded "Figura" and eventually saw its publication in 1938, he must have felt great relief. Against the racist premises of Aryan philology he was able finally to prove the centrality, as well as the validity and credibility, of the Old Testament to the history of Christianity in particular and to Western civilization in general. But this achievement was marred by the gathering clouds and the growing rattle of the drums of war over his beloved Europe. Soon World War II broke out and "Figura," too narrow in its form and content in being only a response to the German crisis of philology, was no longer deemed suitable in his eyes to meeting the challenge of this tremendous historical moment with its severe ramifications for the fate of Western culture and civilization. Accordingly, by 1942, the most crucial year in World War II, Auerbach found his unique voice, his grand singular mission to save the humanist face of Europe. In "Figura," he dealt with an important crisis, the crisis of German philology and its epitome in Aryan philology, clearly a narrow problem in view of the magnanimity and horrors of World War II. Now in 1942, the year of the battles of Stalingrad, Midway and El Alamein, he was more than convinced that "Figura" was no longer an adequate response in view of the evil threatening the humanist soul of Western civilization. No wonder, then, that at the nadir of the war, in 1942, Auerbach had a revelation, an epiphany in Istanbul, which led him to write Mimesis. In this broad historical and philological context, we can say again, in Auerbach's terms, that the essay "Figura" is a figura of Mimesis, or conversely, that Mimesis is the fulfillment and realization of "Figura."

Auerbach's philological philosophical system is based on an analysis of a major, decisive philological turning-point in history, or "semantic development," as Auerbach stated in "Figura" ([21], p. 76). This essay is indeed a clear example of that unique philological way of inquiry. Its ideological and philological origins lay essentially in the reaction to Aryan philology, which signified a radical major important turning-point in literary history, namely from humanist to racial, Aryan philology. Hence, Auerbach enlisted all his philological powers to refute it. Mimesis, on the other hand, is based not on one "semantic development" only but rather on a series of major, decisive philological turningpoints in Western literary history. The tremendous existential risk posed to Western humanist civilization with World War II demanded from him nothing less than a major study which encompassed the whole history of the West. "Figura" was directed against a crisis within German philology, while Mimesis was directed against the crisis of Western culture and civilization as a whole. 
Thus, it is radically different from "Figura," being a long survey of European humanist literary civilization spanning three millennia and eight languages from, as Auerbach significantly stated, "Genesis all the way to Virginia Woolf" [65]. These are revealing words, which clearly defined not only the content and form of Mimesis, but most importantly its ideological, philological agenda, or Auerbach's struggle against Nazi barbarism and un-humanism.

\section{References and Notes}

1. Erich Auerbach. "Introduction: Purpose and Method." In Literary History \& Its Public in Late Latin Antiquity and in the Middle Ages. Princeton: Princeton Univ. Press, 1965 [1958], p. 6.

2. Ibid., p. 6. For Auerbach's life and thought, see: Karlheinz Barck, and Martin Treml (Hrsg.). Erich Auerbach: Geschichte und Aktualität eines europäischen Philologen. Kulturverlag Kadmos. Berlin: Kadmos 2007, and Frank-Rutger Hausmann. "Vom Strudel der Ereignisse verschlungen." Deutsche Romanistik im 'Dritten Reich' (2008).

3. There were many crises in Germany during the first half of the twentieth century; the crisis of ideology, of politics, of theology, of historicism, of culture and of philology-with which we are dealing here-and more. For studies dealing with these various crises, see George L. Mosse. The Crisis of German Ideology: Intellectual Origins of the Third Reich. New York: Grosset \& Dunlap, 1964; Fritz Stern. The Politics of Cultural Despair: A Study in the Rise of the Germanic Ideology. Berkeley and Los Angeles: Univ. of California Press, 1961.

4. It should be noted that the German humanistic and philological crisis of the early twentieth century was inextricably connected to the crisis of historicism. According to Michael Holquist, "the crisis of historicism was in effect a crisis in belief. The long three stage descent from A. belief in an absolute god, through, B. a succeeding belief in the absolute of reason, to C. the 19th century loss of faith in any absolute after the Romantic appropriation of Kantian epistemology led to a re-formulation of subjectivity." Holquist in a personal letter to the authors, July 29, 2011. See also Holquist. "The Place of Philology in an age of world literature." Neohelicon. Forthcoming. See also David Weinstein, and Avihu Zakai. Exile and Interpretation: Reinventing European Intellectual History in the Age of Tyranny. Forthcoming. This study contextualizes ideologically and politically Hans Baron, Erich Auerbach, Leo Strauss and Karl Popper's scholarship.

5. According to William Calin, Auerbach's struggle was not only against Aryan philology. Since Johann Gottfried von Herder, "the German intellectuals have had a wish-fulfillment passion for everything Greek, with the culmination in Heidegger's notion that there are only two truly philosophical languages: Greek and German. Hitler took the trouble to have his picture taken next to (or in front of) the Acropolis. As I see it, this German model was directed not only against the Jewish Old Testament; it also pushed aside the Latin/Roman and, consequently, repudiated the French and Italian traditions." This may also help to explain "why Auerbach centered on French and, to a lesser extent, Italian." Calin in a letter to the authors, 11 July 2011.

6. Suzanne L. Marchand. German Orientalisn in the Age of Empire: Religion, Race, and Scholarship. New York: Cambridge Univ. Press, 2009, p. 316.

7. Erich Auerbach. "Philology and Weltliteratur." The Centennial Review 13, Winter 1969, 4. 
8. Alfred Rosenberg as quoted by Peter M. Head. "The Nazi Quest for an Arian Jesus." Journal for the Study of the Historical Jesus 2 (2004): 69.

9. Susannah Heschel. "Natzifying the Christian theology: Walter Grundmann and the Institute for the Study and Eradication of Jewish Influence on German Church Life." Church History 63 (December 1994): 588. On the German Christian movement, see Doris L. Bergen. Twisted Cross: The German Christian Movement in the Third Reich. Chapel Hill: Univ. of North Carolina Press, 1996; Jack Forstman. Christian Faith in Dark Times: Theological Conflicts in the Shadow of Hitler. Louisville: Westminster, 1992; and Richard Steigmann-Gall's important critical reevaluation of Nazi ideology in The Holy Reich: Nazi Conception of Christianity, 1919-1945. New York: Cambridge Univ. Press, 2003.

10. Waldmar Gurian. Hitler and the Christians. New York: Sheed \& Ward, 1936, p. 68.

11. Victoria Barnett. For the Soul of the People: Protestant Protest against Hitler. New York: Oxford Univ. Press, 1992, pp. 34-35.

12. "GERMANY: New Heathenism." Time, 27 November 1933. http://www.time.com/time/ magazine/article/0,9171,746354,00.html.

13. Mordecai Paldiel. Churches and the Holocaust: Unholy Teaching, Good Samaritans, and Reconciliation. Jersey City: Ktav, 2006, p. 33.

14. See note\# 12.

15. Pamela Eisenbaum. "The Christian Canon and the Problem of Antisemitism." In A Shadow of Glory: Reading the New Testament after the Holocaust, edited by Tod Linafelt. New York: Routledge, 2002, 11. See also E. C. Helmreich. The German Churches under Hitler. Detroit: Wayne State Univ. Press, 1979.

16. Bergen. Twisted Cross, 21. For an important analysis of three distinguished, scholarly, and influential theologians who greeted the rise of Hitler with great enthusiasm and support, see Robert P. Ericksen. Theologians Under Hitler: Gerhard Kittel, Paul Althaus and Emanuel Hirsch. New Haven: Yale Univ. Press, 1985.

17. Vassilis Lambropoulos. The Rise of Eurocentrism: Anatomy of Interpretation. Princeton: Princeton Univ. Press, 1993, p. 11.

18. Lowry Nelson, Jr. "Erich Auerbach: Memoir of a Scholar.” Yale Review 69 (1979-80): 316.

19. René Wellek. "Erich Auerbach (1892-1957). Comparative Literature 10 (1958): 94. See also, Wellek. "Review: Auerbach's Special Realism.” Kenyon Review 16, Spring 1954, 299-307.

20. Auerbach. Mimesis: The Representation of Reality on Western Literature, translated by Willard R. Trask. Princeton: Princeton Univ. Press, [1953] 2003, p. 14.

21. Erich Auerbach. "Figura." 1938, In Auerbach, Scenes from the Drama of European Literature. Gloucester, Mass.: Peter Smith, 1973. All references in the text to "Figura" are to this edition.

22. Jesse M. Gellrich. "Figura, Allegory, and the Question of History." In Literary History and the Challenge of Philology: The Legacy of Erich Auerbach, edited by Seth Lerer. Stanford: Stanford Univ. Press, 1996, 111. According to Martin Elsky in a personal letter to the authors, July 1, 2011, "Gellrich is right about Auerbach starting 'Figura' in Marburg just before leaving for Istanbul. I believe the evidence appears in Auerbach's letter to Karl Vossler, 15 September 1935. Auerbach is considering Spitzer's proposal that he replace him in Istanbul when Spitzer leaves for Hopkins, though he's still hoping for a possibilities in Europe. Towards the end of the letter he remarks: 
'Concerning my own work on realism, that will have to wait a while, there may still be more to get out of it.' This is usually interpreted as a reference to his start on 'Figura,' begun that is on the eve of his move to Istanbul, where it was completed. He comments on the importance of the essay in a letter from Istanbul to his student in Marburg, Martin Hellweg, 22 May 1939. Both letters appeared in a translation in "Scholarship in the Age of Extremes," PMLA 2007, 742ff. In the above mentioned letter to Vossler, Auerbach wrote that "my work of realism" will "have to wait a while; there may still be more to get out of it." See Auerbach. "Letter to Dr. Karl Vossler." 15 September 1935, In "Scholarship in the Age of Extremes." 747.

23. Gellrich. "Figura, Allegory, and the Question of History." 111.

24. Hayden White. "Auerbach's Literary History: Figural Causation and Modernist Historicism." In Literary History and the Challenge of Philology: The Legacy of Erich Auerbach, edited by Seth Lerer. Stanford: Stanford Univ. Press, 1996, p. 125. Note that Auerbach rather rejected the notion of "figural causation," claiming in Mimesis that "figural interpretation" is "established between two events which are linked neither temporally nor causally-a connection which is impossible to establish by reason in the horizontal dimension." See Mimesis, p. 73.

25. Louis G. Kelley. "Auerbach, Erich." In Encyclopedia of Contemporary Literary Theory: Approaches, Scholars, Terms, edited by I. R. Makaryk. Toronto: Univ. of Toronto Press, 1993, p. 235: "In an absolute sense there is little new in what Auerbach writes about figura: any theologian who knows his Aquinas or medieval mystics will still find no surprises in Auerbach's exposition, except that Auerbach's wholesale application of the idea to literature, and to Dante in particular, would take him aback."

26. Galili Shahar. "Auerbach's Scars: Judaism and the Question of Literature." Jewish Quarterly Review 101, Fall 2011, 611.

27. Erich Auerbach. "Epilegomena to Mimesis." 1953, In Mimesis, p. 568. Hegel greatly influenced Auerbach's formation of the notion of figura. See Frank R. Ankermist. "Why Realism? Auerbach on the Representation of Reality." Poetic Today 20, Spring 1999, 62, n. 18.

28. A. D. Nuttall. “Auerbach's Mimesis.” Essays in criticism 54 (2004): 68.

29. Carl Landauer. "Mimesis' and Erich Auerbach's Self-Mythologizing." German Studies Review 11, February 1988, 90.

30. See ref. 20, p. 74.

31. Gellrich. "Figura, Allegory, and the Question of History." 108.

32. Claus Uhlig. “Auerbach's 'Hidden'? Theory of History." In Literary History and the Challenge of Philology: The Legacy of Erich Auerbach, edited by Seth Lerer. Stanford: Stanford Univ. Press, 1996, 47.

33. Gellrich. "Figura, Allegory, and the Question of History." 107-9. For Auerbach's concept of Ansatzpunkt, see Said, Beginnings: Intention and Method. New York: Basic Books, 1975.

34. The quote from Augustine appeared in a letter to the authors from Professor Jesse M. Gellrich, July 5, 2011.

35. See ref. 20, p. 156.

36. White. "Auerbach's Literary History." p. 128.

37. See ref. 20, p. 73.

38. Ibid., pp. 156-7. 
39. Lowry Nelson, Jr. "Erich Auerbach: Memoir of a Scholar.” Yale Review 69 (1979-80): 316.

40. Uhlig. "Auerbach's 'Hidden'? Theory of History," 47.

41. For Auerbach, the Enlightenment of the eighteenth century, with its de-sacralization and disenchantment of the world, put an end to traditional figural interpretation. For the Enlightenment's struggle against the Christian re-enchantment of the world, see Avihu Zakai. Jonathan Edwards's Philosophy of History: The Re-Enchantment of the World in the Age of Enlightenment. Princeton: Princeton Univ. Press, 2003; and Jonathan Edwards's Philosophy of Nature: The Re-Enchantment of the World in the Age of Scientific Reasoning. London: T\&T Clark, 2010.

42. Vassilis Lambropoulos. The Rise of Eurocentrism: Anatomy of Interpretation. Princeton: Princeton Univ. Press, 1993, p. 11.

43. Landauer. "'Mimesis' and Erich Auerbach's Self-Mythologizing." 90.

44. Geoffrey Green. Literary Criticism and the Structure of History: Erich Auerbach and Leo Spitzer. Lincoln: University of Nebraska Press, 1982, p. 35.

45. See note \# 22, pp. 108-9.

46. Brian Stock. "Literary Realism in the Later Ancient period." In Literary History and the Challenge of Philology: The Legacy of Erich Auerbach, edited by Seth Lerer. Stanford: Stanford Univ. Press, 1996, p. 144.

47. See note \# 20, p. 73.

48. See ref. 28, p. 71 .

49. See ref. 20, p. 73.

50. Gellrich.“Figura, Allegory, and the Question of History.” pp. 107-9.

51. Ibid., p. 110.

52. See ref. 20, p. 48.

53. Ibid., p. 48.

54. Michael Holquist. "The Last European: Erich Auerbach as Precursor in the History of Cultural Criticism.” Modern Language Quarterly 54 (1993): 380.

55. See ref. 20, p. 16.

56. Edward W. Said. "Introduction: Secular Criticism." In Said, The Word, The Text, and the Critic. Cambridge, Mass.: Harvard Univ. Press, 1983, p. 8. See also Said. "Reflections on Exile." 1984, in Said, Reflections on Exile and Other Essays. Cambridge, Mass.: Harvard Univ. Press, 2000, p. 186.

57. Auerbach. "Epilogue," In Mimesis, p. 557.

58. Nelson. "Erich Auerbach.” p. 319.

59. Ibid., pp. 314-5.

60. Gellrich. "Figura, Allegory, and the Question of History." 110. An excellent analysis of Auerbach's first chapter of Mimesis, "Odysseus Scare," can be found James I. Porter. "Erich Auerbach and the Judaising of Philology." Critical Inquiry 35, Autumn 2008, 115-47.

61. See ref. 20, p. 16.

62. Auerbach. Dante: Poet of the Secular World. Chicago: University of Chicago Press, 1961 [1929], p. 60 .

63. See ref. 28, p. 69. 
64. Ibid., p. 69.

65. Auerbach. "Appendix: 'Epilegomena to Mimesis."” p. 563.

(C) 2012 by the authors; licensee MDPI, Basel, Switzerland. This article is an open access article distributed under the terms and conditions of the Creative Commons Attribution license (http://creativecommons.org/licenses/by/3.0/). 